\title{
Plane Wall Effect of Flow around Two Circular Cylinders in Tandem Arrangement
}

\author{
Triyogi Yuwono ${ }^{1}$, Wawan Aries Widodo ${ }^{1}$, Heru Mirmanto ${ }^{1}$, and Fahmi Fahreza ${ }^{1}$
}

\begin{abstract}
The flow characteristic around two circular cylinders in tandem arrangement located near a plane wall were investigated experimentally in a uniform flow at a Reynolds Number of $5.3 \times 10^{4}$. The center to center spacing between the two cylinders relative to the cylinder diameter was constantly maintained at $P / D=1.5$. The pressure distributions along the surface of the cylinder and the plane wall were measured by varying the gap-to-diameter of cylinder ratio (G/D) in the range of $0 \leq G / D \leq 0.467$. Surface oil-film techniques were used to investigate the flow patterns on the cylinder. The result showed that for upstream cylinder, in the gap-to-diameter ratio G/D $<\delta / D$, there is no stagnation point at front side of the upstream cylinder; it is gradually raised as the gap increase. For the downstream cylinder, a peak on the lower side of the front side of the cylinder is apparent in each of the pressure distributions. This peak represents the reattachment of shear layer that separates from lower side of the upstream cylinder. The reattachment point tends to move forward close to the angular position of $\theta=\mathbf{0}^{\circ}$ as the gap ratio increase. The shear layer bifurcates into two shear layers. One shear layer continues in the downstream direction, and the other shear layer flows in the upstream direction.
\end{abstract}

Keywords — circular cylinders, gap-to-diameter of cylinder ratio, plane wall, tandem arrangement

Abstrak-Dalam penelitian ini telah diamati secara eksperimen karakteristik aliran melintasi silinder ganda yang tersusun secara tandem di dekat dinding datar, untuk aliran seragam (uniform flow) dengan bilangan Reynolds, Re =5,3 x 10 ${ }^{4}$. Untuk jarak antar titik pusat kedua silinder ditetapkan konstan sebesar $P / D=1,5$, distribusi tekanan sepanjang permukaan kedua silinder dan dinding datar diukur dengan memvariasikan rasio antara gap dinding dengan silinder dan diameter silinder (G/D) dalam rentang $0 \leq G / D \leq 0,467$. Metode surface oil-film digunakan untuk memvisualisasikan bentuk aliran pada silinder. Hasil eksperimental menunjukan bila rasio jarak gap $G / D<$ rasio antara tebal lapis batas dan diameter (D/D) tidak terjadi titik stagnasi di bagian depan dari silinder upstream; namun stagnasi berangsur-angsur muncul sejalan dengan meningkatnya jarak gap. Sedangkan untuk silinder downstream, pada setiap distribusi tekanan yang diukur terdapat puncak tekanan pada sisi bawah dari bagian depan silinder. Puncak ini menunjukkan posisi reattachment dari shear layer yang terseparasi dari bagian bawah silinder upstream. Sejalan dengan meningkatnya rasio gap, titik reattachment cenderung bergerak maju mendekati posisi $\theta=0^{\circ}$. Shear layer terbagi menjadi dua di mana salah satu shear layer menuju ke arah downstream sedangkan shear layer yang lain menuju ke arah upstream.

Kata Kunci-silinder sirkular, rasio gap antara dinding dengan silinder, dinding datar, susunan tandem

\section{INTRODUCTION}

A circular cylinder is one of the elementary shapes of stuctures used in engineering practice, and several cylinders are often used in groups. Different studies show that many interesting and unexpected fluid phenomena may occur when bodies are placed one beside the other, and grouping effect of bodies is a very interesting subject of fundamental research in fluid mechanics [1]. Two circular cylinders in tandem arrangement is a simple case of an array of multiple structures. Moreover, this array of multiple circular cylinders are also often located near a flat plate, and it is an interesting topic to be investigated. This kind of study can be applied to many engineering problems such as undersea pipelines, building constructions, and tubes in heat exchangers, etc.

In the previous research, there are many studies on circular cylinders as research subject, such as two circular cylinders in tandem arrangement or a circular cylinder placed near a wall. For two circular cylinders in tandem arrangement the authors pointed out that bistable flow occurs at a critical spacing, and before this critical spacing fluctuating lift and drag forces acting on the downstream cylinder are very sensitive to the spacing between the cylinders [1]. For a circular cylinder placed

Triyogi Yuwono, Wawan Aries Widodo, Heru Mirmanto and Fahmi Fahreza are with Department of Mechanical Engineering, FTI, Institut Teknologi Sepuluh Nopember, Surabaya, 60111, Indonesia, E-mail: triyogi@me.its.ac.id. near a plane wall, the author reported that drag coefficient of cylinder was almost unaffected by the gap-todiameter ratio until the gap was about the same as the thickness of the wall boundary layer, but lift coefficient depended strongly on the gap-to-diameter ratio [2]. In addition, the authors confirmed that as the gap ratio increases, the drag coefficient of the cylinder is increased [3]. Despite the larger number of studies on both two circular cylinders in tandem arrangement and circular cylinder placed near a plane wall, there have been very few studies on two circular cylinders in tandem arrangement placed near a plane wall. Hence, the aim of this study is to investigate the characteristics of flow of two circular cylinders in tandem arrangement placed near a plane wall.

This study, on the relatively simple case of two stationary circular cylinders of equal diameters in tandem arrangement with constant spacing are placed near a plane wall. It is subjected to a steady cross flow with varying gaps between wall and cylinders.

\section{METHOD}

The experiments were carried out in a subsonic open circuit wind tunnel with test section of $660 \mathrm{~mm}$ in height, $660 \mathrm{~mm}$ in width, and $1,780 \mathrm{~mm}$ in length. Figure 1 shows a schematic diagram of the cylinder configurations and different parameters under investigation. Two PVC tubes were used as models which had external diameters, $D$, of $60 \mathrm{~mm}$ and at the two ends of the cylinders spanning the wind tunnel test- 
section. It gives length to diameter ratio and geometric blockage ratio (diameter-to-wind tunnel height ratio) was the same value of $9.1 \%$. As a plane wall, a smooth acrylic flat plate of $6 \mathrm{~mm}$ in thickness and 1,160 $\mathrm{mm}$ in length was installed $100 \mathrm{~mm}$ above the bottom surface of the test section. The leading edge of the plate was sharpedge with an angle of $30^{\circ}$. The upstream of cylinders arrangement was located at $430 \mathrm{~mm}$ downstream from the leading edge of the flat plate.

The free stream velocities in the wind tunnel was constantly maintained at $14 \mathrm{~m} / \mathrm{s}$, corresponding to Reynolds number of $R_{e}=5.3 \times 10^{4}$ (based on diameter of circular cylinder $D$ and the free stream velocity). The boundary layer thickness formed over the flat plate at the upstream cylinder location has been measured as $\delta=$ $15.2 \mathrm{~mm}$. The center to center spacing between the two cylinders relative to the cylinder diameter was constantly maintained at $P / D=1.5$. The gap distance between the bottom of the cylinders and the plane wall relative to the cylinder diameter (G/D) were varied from 0 to 0.467 . To measure the pressure distribution on the cylinders surface and on the plane wall, the 72 pressure taps with interval $5^{\circ}$ were installed on the wall of circular cylinder and the 52 pressure taps were installed on the plane wall at $-5 \leq x / D \leq 10.5$, where $x / D=0$ is the positon of the center of upstream cylinder. The pressure taps were connected to an inclined kerosene manometer, it makes possible to measure the pressure distribution around the circular cylinder. Room temperature was measured using a thermometer, and this temperature was used to calculate the fluid density and viscosity. Surface oil-film techniques were used to investigate the flow patterns on the circular cylinder. A mixture composed of kerosene, titanium dioxide, silicone oil with ratio of 1:4:1 in weight was used for surface oil-flow visualization. The circular cylinders wrapped in a black paper of $0.2 \mathrm{~mm}$ in thickness was uniformly smeared with the mixture, and then cylinders in configuration were placed inside the wind tunnel to obtain a surface oil-flow pattern. Finally, the paper was carefully unwrapped from the cylinder, and a photograph was taken by using a digital camera.

\section{RESULTS AND DISCUSSION}

\section{A. Pressure Distribution}

The pressure coefficient $\left(\mathrm{C}_{\mathrm{p}}\right)$ distributions around the upstream cylinder at the Reynolds number $(R e)=5.3 \mathrm{x}$ $10^{4}$ are shown in Figure 2.

The Figure 2 (a) shows the distribution of $\mathrm{C}_{\mathrm{p}}$ of upstream cylinder for $\mathrm{G} / \mathrm{D} \leq 0.2$ compared to the distribution of $\mathrm{C}_{\mathrm{p}}$ of upstream cylinder positioned at the centerline of wind tunnel. The results show that the distributions of $\mathrm{C}_{\mathrm{p}}$ are completely asymmetric. It is important to be noted that for $\mathrm{G} / \mathrm{D} \leq 0.2$ or $\mathrm{G} / \mathrm{D}<\delta / \mathrm{D}$ (where $\delta / D=0.253$ ) there is no stagnation point with $C_{p}$ $=1$ at front side of the upstream cylinder. This absent of the stagnation point at the upstream cylinder is due to the position of cylinder being close to the plane wall. The blockage effect in the gap between the cylinder and the plane wall causes a large part of fluid flows to the upper side of cylinder. It causes no streamline coming orthogonally to the cylinder. For $\mathrm{G} / \mathrm{D} \leq 0.2$, the position of the separation points are aft of that one of the tandem arrangement positioned at the centerline of wind tunnel.
The Figure 2 (b) shows the distribution of $\mathrm{C}_{\mathrm{p}}$ for $0.2<$ $\mathrm{G} / \mathrm{D} \leq 0.467$ compared to the distribution of $\mathrm{C}_{\mathrm{p}}$ at the centerline of wind tunnel. The results show that the distributions of $\mathrm{C}_{\mathrm{p}}$ tend to be more symmetric than the $\mathrm{C}_{\mathrm{p}}$ of $\mathrm{G} / \mathrm{D} \leq 0.2$. In these gaps, the stagnation points are gradually raised and the position of the separation points are still aft of that one of the tandem arrangement positioned at the centerline of wind tunnel.

Figure 3 shows the pressure coefficient $\left(C_{p}\right)$ distributions around the downstream cylinder at the Reynolds number $(R e)=5.3 \times 10^{4}$. Figure 3 (a) shows the distribution of $C_{p}$ of downstream cylinder for $G / D \leq$ 0.2. The results show that the distributions of $C_{p}$ are completely asymmetric. A peak on the lower side of the front side of the downstream cylinder is apparent in each of the pressure distributions. This peak represents the reattachment of shear layer that separates from lower side of the upstream cylinder. The reattachment point tends to move forward close to the angular position of $\theta$ $=0^{\circ}$ as the gap ratio increases. From the reattachment points, the shear layer bifurcates into two shear layers. One shear layer continues in the downstream direction and the other shear layer flows in the upstream direction, which the authors called the backward and the forward shear layers, respectively [1]. The backward shear layer separates at $\theta=230^{\circ}-240^{\circ}$, depending on the gap ratio, where the separation point tends to precipitate occur as the gap ratio increase. For $\mathrm{G} / \mathrm{D}=0.067$, the backward shear layer separates at $\theta=230^{\circ}$ and the forward shear layer separates at $\theta=35^{\circ}$.

Moreover, the shear layer separates from the upper side of the upstream cylinder covers the upper side of the downstream cylinder, and there is no reattachment phenomena in this case. These tendencies are also observed for $0.267 \leq \mathrm{G} / \mathrm{D} \leq 0.467$, as shown in Figure 3(b). In general, the tandem arrangement with $\mathrm{P} / \mathrm{D}=1.5$ and for $\mathrm{G} / \mathrm{D} \leq 0.467$, the alternate reattachment phenomena occurred, as stated by the author [4].

Figure 4 shows the pressure distribution along the plane wall as function of the gap ratio between the cylinder arrangement and the wall (G/D) for $\operatorname{Re}=5.3 \mathrm{x}$ $10^{4}$. The pressures were measured in range of $-5 \leq \mathrm{X} / \mathrm{D} \leq$ 10.5. Figure 4 (a) shows the pressure distribution along the plane wall for $G / D \leq 0.2$. The results show that the upstream surface pressure decreases as the gap ratio increases. Two minimum pressures are observed at the downstrean of each cylinders, and these minimum pressures increase as the gap ratio increases. As the flow moves downstream, the negative pressures recover to static pressure. It is also observed that the location of minimum pressures move downstream as the gap ratio increase. These tendencies are also observed for $0.267 \leq$ $\mathrm{G} / \mathrm{D} \leq 0.467$, as shown in Figure 4 (b).

Figure 5 (a), (b) and (c) show the comparison of pressure distibutions for $\mathrm{G} / \mathrm{D}=0.067$ between present results and numerical results by the authors, for cylinder upstream, cylinder downstream and plane wall respectively [5]. As indicated in Figure 5 (a), for cylinder upstream, the result of comparison does not always agree. Based on the numerical result by authors, the flows were accelerated in the lower side (in the gap between cylinder and plane wall), it is contrary to the experimental result of this present study [5]. For the downstream cylinder, the result of comparison gives 
enough agreement, as shown in Figure 5 (b). Enough agreement was also shown by the result of comparison between the present study and numerical results by [5] for pressure distribution at the plane wall, as shown in Figure 5 (c).

Figure 6 (a), (b) and (c) show the comparison of pressure distibutions for $\mathrm{G} / \mathrm{D}=0.267$ between present study and numerical results by authors [5]. For cylinder upstream, cylinder downstream and plane wall respectively. As indicated in Figure 6 (a), for cylinder upstream, the result of comparison give close agreement. Moreover, for the downstream cylinder, the result of comparison gives good agreement, as shown in Figure 6 (b). A good agreement was also shown by the result of comparison between the present study and numerical results by [5] for pressure distribution at the plane wall, as shown in Figure 6 (c).

\section{B. Coefficient of Drag and Lift}

Figure 7 (a) and (b) show respectively the evolution of the pressure drag $\left(\mathrm{C}_{\mathrm{Dp}}\right)$ and lift coefficient $\left(\mathrm{C}_{\mathrm{Lp}}\right)$ of circular cylinder in tandem arrangement for varied gaps G/D. For investigating more deeply the influence of the gap-to-diameter of cylinder ratio $(\mathrm{G} / \mathrm{D})$ to the $\mathrm{C}_{\mathrm{Dp}}$ and $\mathrm{C}_{\mathrm{Lp}}$, the gap was extended until $\mathrm{G} / \mathrm{D}=1.0$.

As indicated in Figure 7 (a), for upstream cylinder the coefficient of pressure drag $\left(\mathrm{C}_{\mathrm{Dp}}\right)$ tends to increase as the gap increase for $\mathrm{G} / \mathrm{D} \leq 0.467$. Then $\mathrm{C}_{\mathrm{Dp}}$ will be practically close to the coefficient pressure drag of the upstream cylinder in the centerline of wind tunnel $\left(\mathrm{C}_{\mathrm{Dp0}-1}\right.$ $=1.03$ ), when the gap increase for $\mathrm{G} / \mathrm{D}>0.467$. For downstream cylinder, the $C_{D p}$ tends to be zero when the gap increase for $G / D \leq 0.467$. For the gap $G / D$ more than 0.467 , the $C_{\text {Dp }}$ tends to decrease close to the coefficient of pressure drag of the downstream cylinder in the centerline of wind tunnel $\left(\mathrm{C}_{\mathrm{Dp} 0-2}=-0.3\right)$. Figure $7(\mathrm{~b})$ shows that the coefficient of pressure lift $\left(\mathrm{C}_{\mathrm{Lp}}\right)$ of the upstream cylinder tends to decrease as the gap increases for $\mathrm{G} / \mathrm{D}<0.467$. Then the $\mathrm{C}_{\mathrm{Lp}}$ will close to zero as the gap increases for $\mathrm{G} / \mathrm{D}>0.467$. It means that, in general for $G / D>0.467$, the interaction beetween the plane wall and cylinder will be weak and the flow distributions will be symmetric as the gap increases. It will give the value $\mathrm{C}_{\mathrm{Dp}}$ come near to $\mathrm{C}_{\mathrm{Dp} 0}$ and the value of $\mathrm{C}_{\mathrm{Lp}}$ tends to zero.

Furthermore, this ratio of gap to cylinder diameter $(G / D>0.467)$ is clearly more than the ratio of boundary layer thickness to cylinder diameter $(\delta / D=0.253)$. It means that the position of cylinder is in the outside of boundary layer, so the influence of boundary layer to the flow around the cylinder becomes weaker than if the cylinder is closed to the plan wall.

\section{Flow Visualization}

Figure 8 shows the results of flow visualization at the wall of the upstream and downstream cylinders using the surface oil-flow pattern method for $\mathrm{G} / \mathrm{D}=0.067$ and $R e$ $=5.3 \times 10^{4}$. The result obtained by authors [5] is also included in the same figure for comparison. It seems that the result of comparison gives a good agreement.

1. The shear layer separates from the lower side of upstream cylinder at $\theta=260^{\circ}$ and attaches to the downstream cylinder at $\theta=300^{\circ}$. From this reattachment point, the shear layer bifurcates into two shear layers. The backward shear layer separates at $\theta=240^{\circ}$ and the forward shear layer separates at $\theta=20^{\circ}$. Due to the position of the upstream cylinder, this forward shear layer reattaches to the downstream cylinder at $\theta$ $=90^{\circ}$. It seems that the vortex was observed between $\theta=20^{\circ}$ and $\theta=90^{\circ}$. These phenomena were covered by the shear layer separation from the upper side of the upstream cylinder at $\theta=80^{\circ}$.

\section{CONCLUSION}

The results of this investigation may be summarized as follows:

1. For upstream cylinder, in the gap-to-diameter ratio $\mathrm{G} / \mathrm{D}<\delta / \mathrm{D}$, there is no stagnation point with $\mathrm{C}_{\mathrm{p}}=1$ at front side of the upstream cylinder. At these gaps, the position of the separation points are aft of that of the tandem arrangement positioned at the centerline of wind tunnel. As the gap-to-diameter ratio (G/D) increases, the distributions of $\mathrm{C}_{\mathrm{p}}$ tends to be more symmetric than the $C_{p}$ of $G / D<\delta / D$. For $G / D \geq$ 0.267 , the stagnation points are gradually raised and the position of the separation points are still aft of that of the tandem arrangement positioned at the centerline of wind tunnel.

2. For the downstream cylinder, a peak on the lower side of the front side of the cylinder is apparent in each of the pressure distributions. This peak represents the reattachment of shear layer that separates from lower side of the upstream cylinder. The reattachment point tends to move forward close to the angular position of $\theta=0^{\circ}$ as the gap ratio increases. From the reattachment points, the shear layer bifurcates into two shear layers. One shear layer continues in the downstream direction called the backward shear layer, and the other shear layer flows in the upstream direction called the forward shear layer. Moreover, the shear layer separates from the upper side of the upstream cylinder covers the upper side of the downstream cylinder, and there is no reattacment phenomena in this case. These tendencies are also observed for $0.267 \leq \mathrm{G} / \mathrm{D} \leq 0.467$.

\section{NOMENCLATURE}

$\mathrm{C}_{\mathrm{p}} \quad$ coefficient of pressure

D diameter of the cylinders

$\left(\mathrm{p}-\mathrm{p}_{\infty}\right) /\left(0,5 \rho \mathrm{U}_{\mathrm{o}}^{2}\right)$

$\delta$ boundary layer thickness at the upstream of cylinders location (m)

$\mathrm{G}$ gap distance between the bottom of the cylinders and the plane wall

$\mathrm{p} \quad$ surface pressure of the cylinders the center to center spacing between the two cylinders

$\mathrm{p}_{\infty} \quad$ free stream pressure

$\left(\mathrm{N} / \mathrm{m}^{2}\right)$

$\theta$ angular position

(degree)

$\mathrm{U}_{\mathrm{o}} \quad$ free stream velocity

$\rho \quad$ free stream density

$\mathrm{X}$ longitudinal distance at the plane wall

\section{REFERENCES}

[1] M.M. Alam, M. Moriya, K. Takai, and H. Sakamoto, "Fluctuating fluid forces acting on two circular cylinders in a tandem arrangement at a subcritical Reynolds number" Journal of Wind Engineering and Industrial Aerodynamics, Vol. 91, pp.139154, 2003. 
[2] M.M. Zdravkovich, "Forces on circular cylinder near a plane wall", Applied Ocean Research, Vol. 7 (4), pp.197 - 201, 1985.

[3] J. H. Choi and S. J.Lee, "Ground effect of flow around an elliptic cylinder in a turbulent boundary layer", Journal of Fluids and Structure, Vol. 4, pp. 697-709, 2000.

[4] M.M. Zdravkovich, "Classification of Flow-induced oscillations of two parallel circular cylinders in variuous arrangement", International Symposium on Flow-Induced Vibration, Vol. 2, pp.1-18, 1985.

[5] W.A. Widodo, T. Yuwono, and H. Mirmanto, "Numerical simulation flow across two cylinders in a tandem arrangement in side wall effect for various gap ratio", Proceeding of Mechanical Engineering Annual Seminar-VIII (SNTTM-VIII), SemarangIndonesia, 2009.

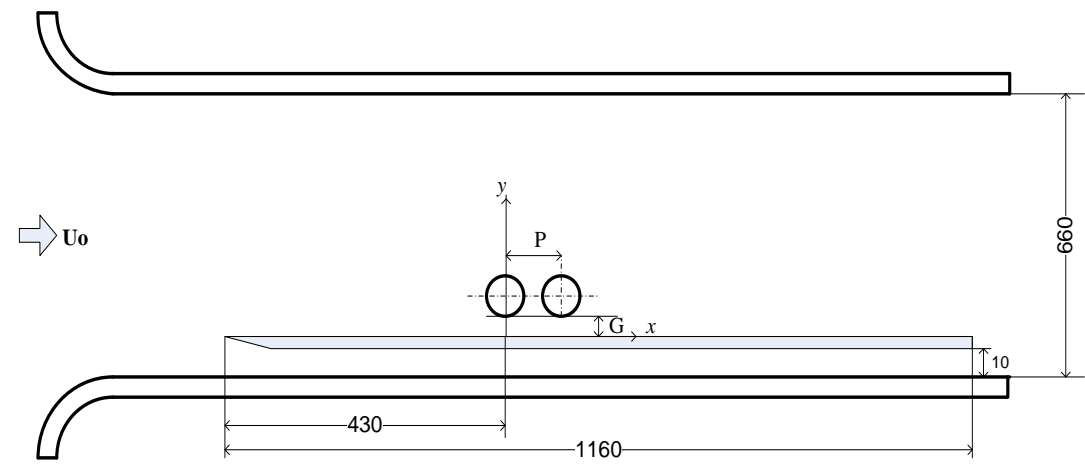

Figure 1. Schematic diagram of experimental set-up (dimensions: $\mathrm{mm}$ )

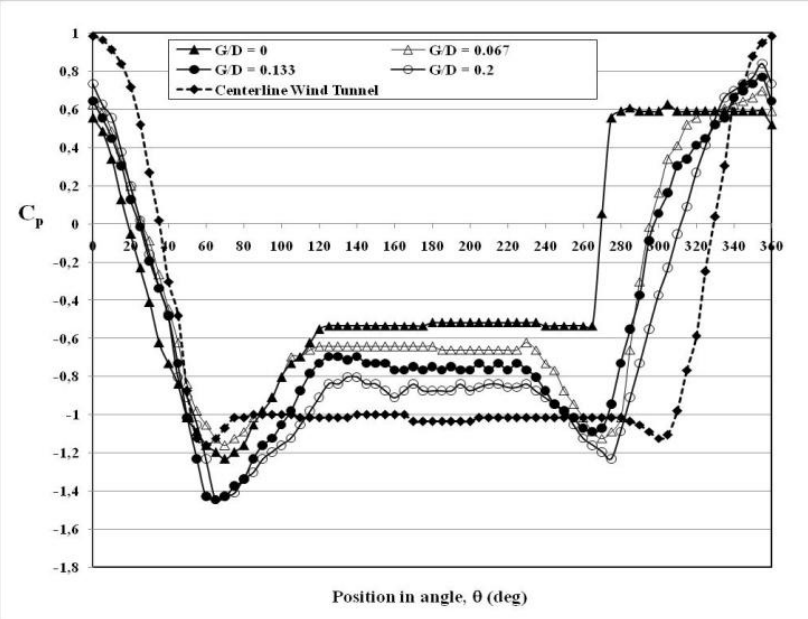

(a)

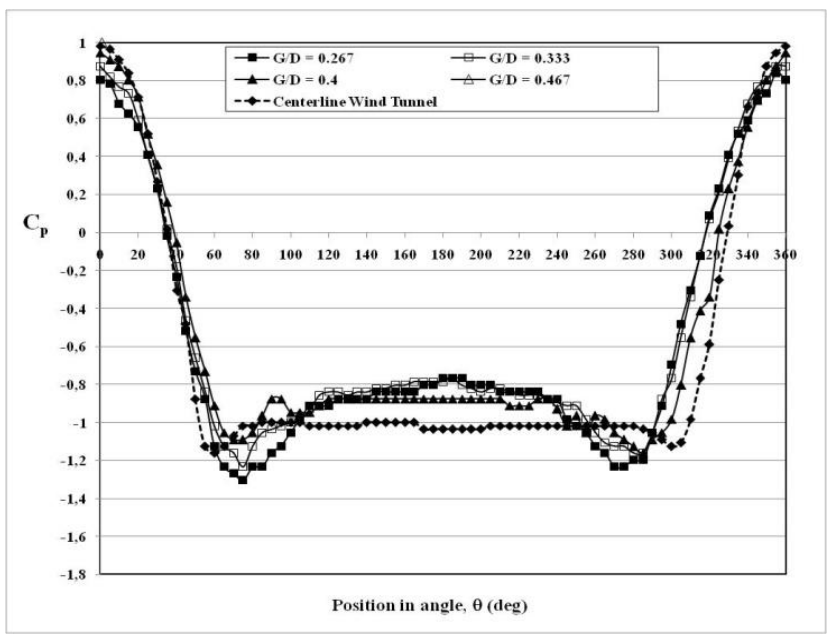

(b)

Figure 2. Pressure distribution around upstream cylinder for $\mathrm{Re}=5.3 \times 10^{4}$ : (a) $0 \leq \mathrm{G} / \mathrm{D} \leq 0.2$, (b) $0.267 \leq \mathrm{G} / \mathrm{D} \leq 0.467$

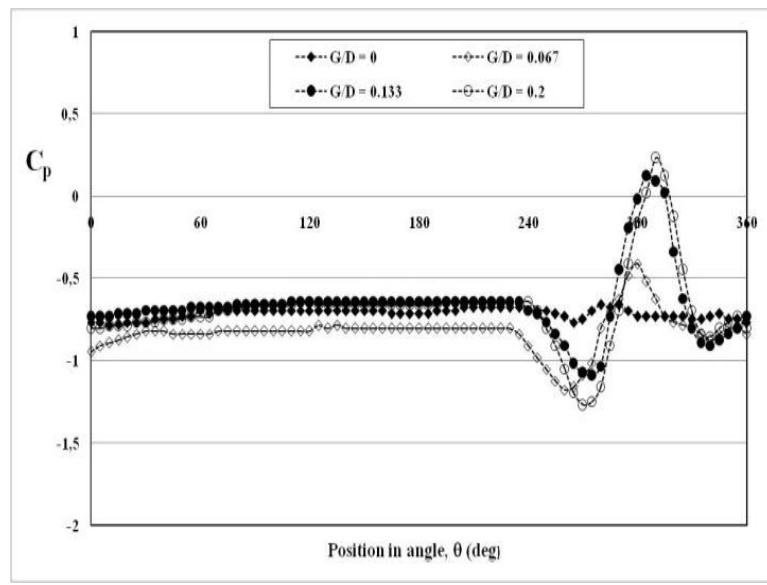

(a)

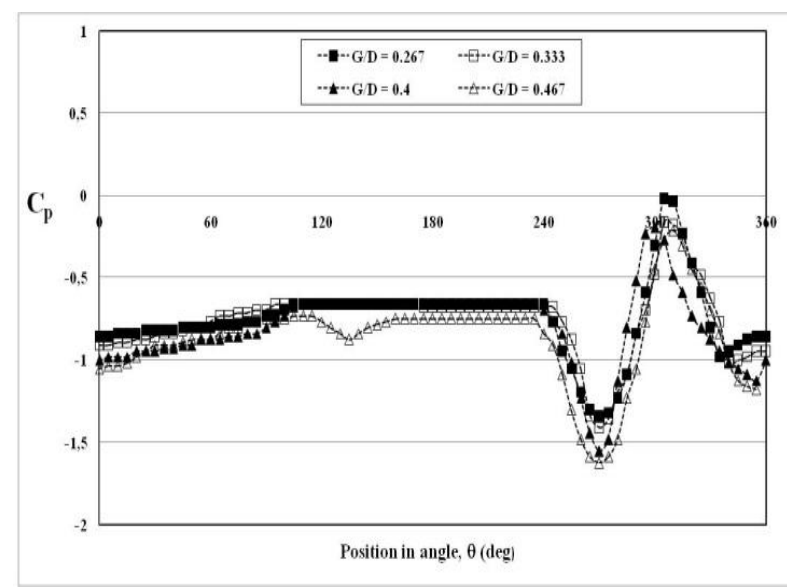

(b)

Figure 3. Pressure distribution around downstream cylinder for $\mathrm{Re}=5.3 \times 10^{4}$ : (a) $0 \leq \mathrm{G} / \mathrm{D} \leq 0.2$, (b) $0.267 \leq \mathrm{G} / \mathrm{D} \leq 0.467$ 


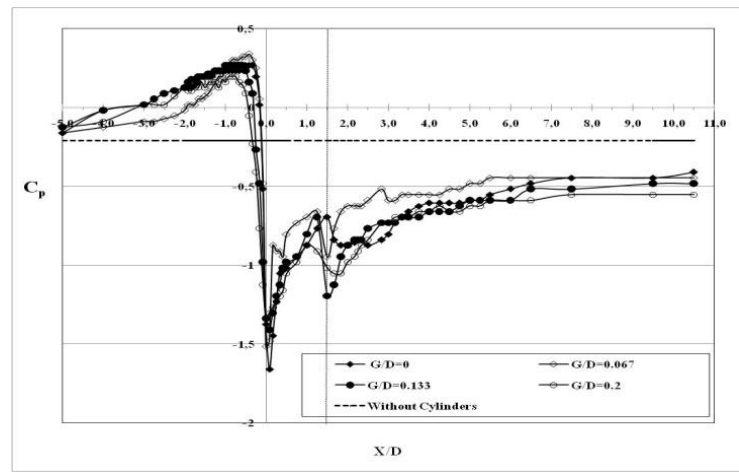

(a)

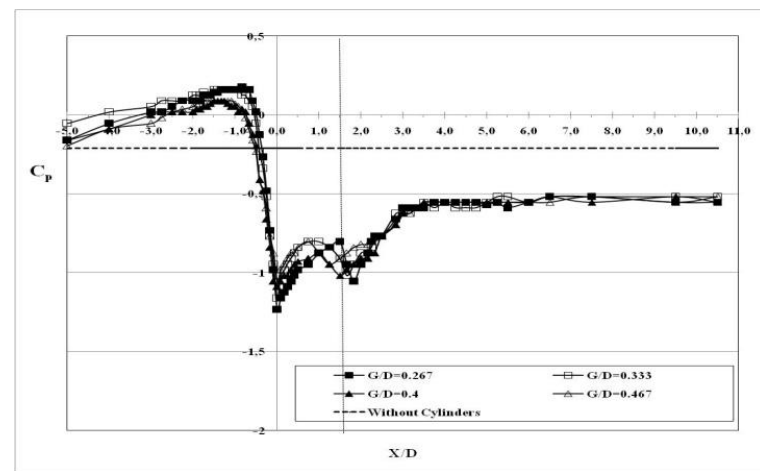

(b)

Figure 4. Pressure distribution along the plane wall as function of the gap-to-diameter ratio for $R_{e}=5.3 \times 10^{4}$ : (a) $0 \leq G / D \leq 0.2$, (b) $0.267 \leq G / D$ $\leq 0.467$

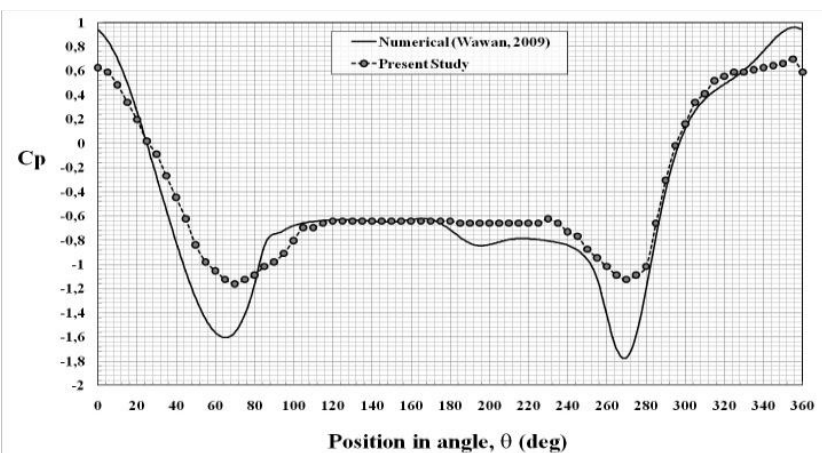

(a)

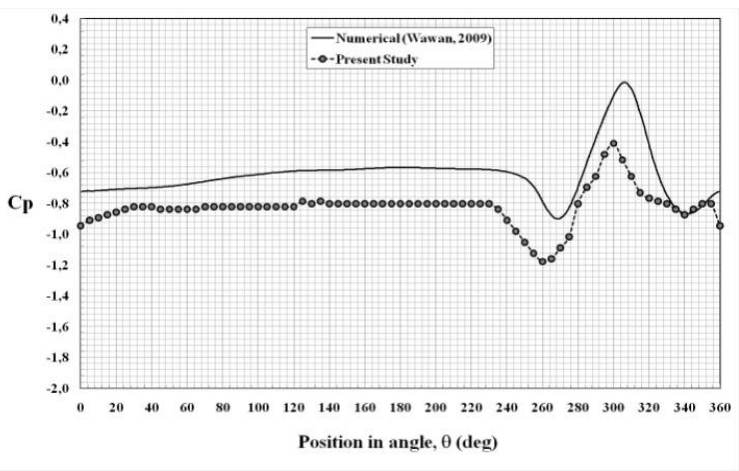

(b)

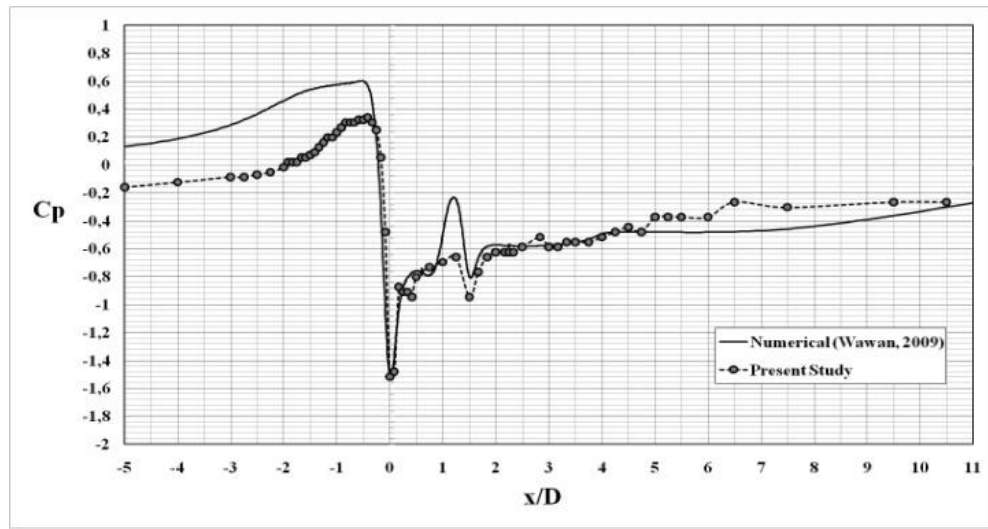

(c)

Figure 5. Pressure distribution for $\mathrm{G} / \mathrm{D}=0.067$ and $\mathrm{R}_{\mathrm{e}}=5.3 \times 10^{4}$, in comparison between the present study and numerical results by [5]: (a) cylinder upstream, (b) cylinder downstream, and (c) plane wall 


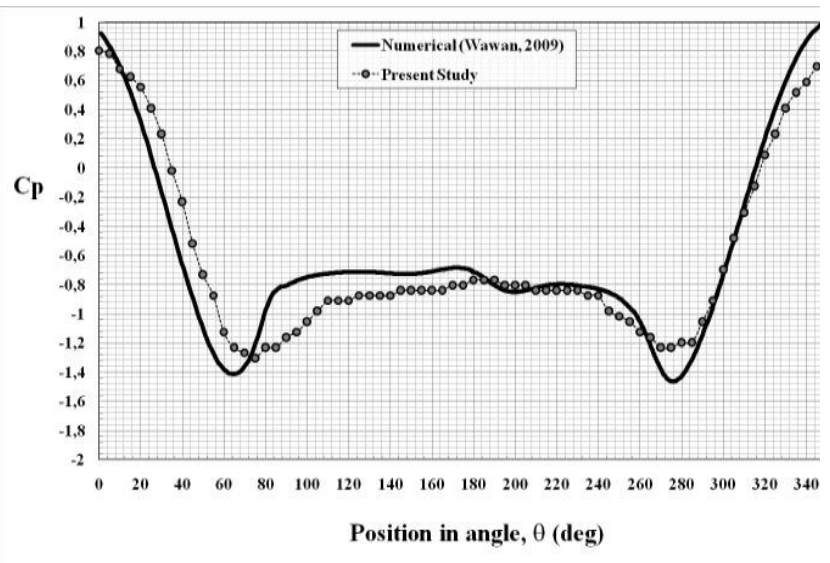

(a)

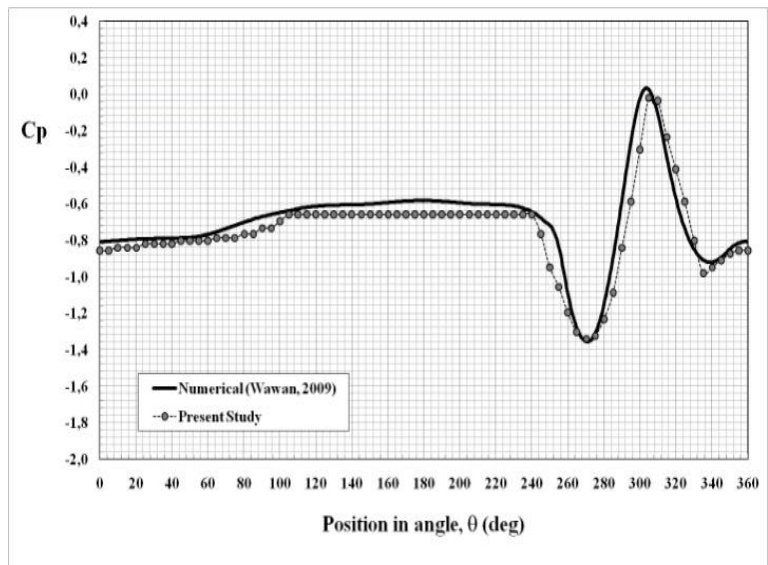

(b)

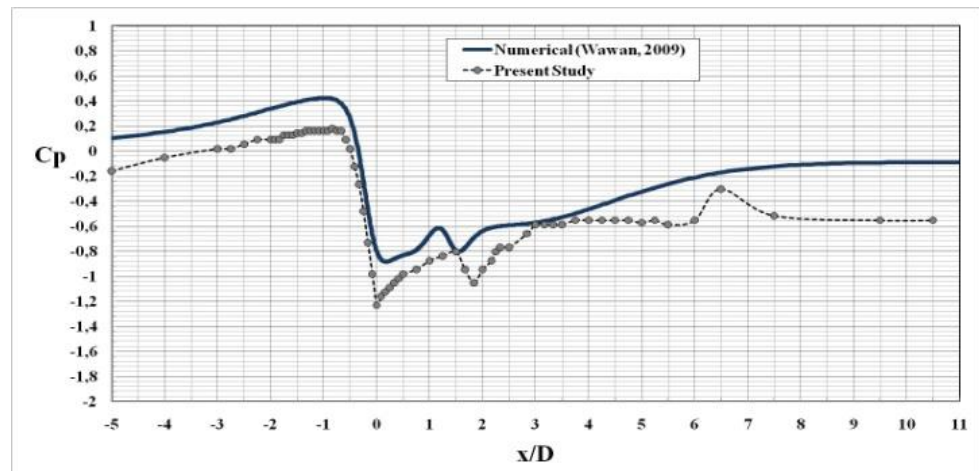

(c)

Figure 6. Pressure distribution for $\mathrm{G} / \mathrm{D}=0.267$ and $\mathrm{R}_{\mathrm{e}}=5.3 \times 10^{4}$, in comparison between the present study and numerical results by [5]: (a) cylinder upstream, (b) cylinder downstream, and (c) plane wall

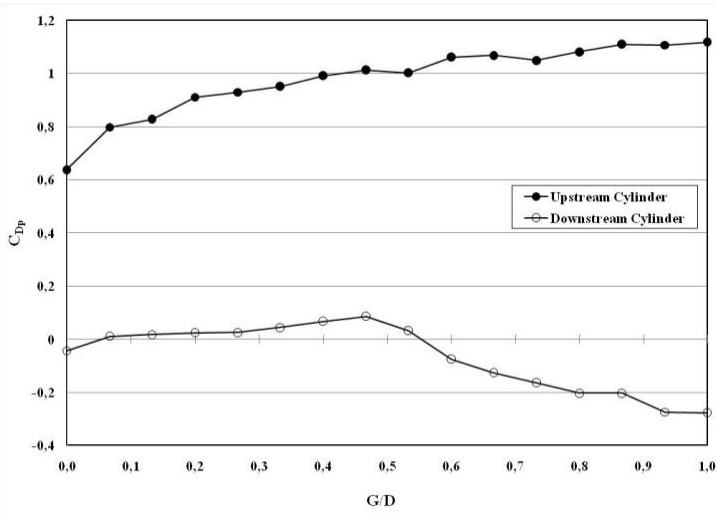

(a)

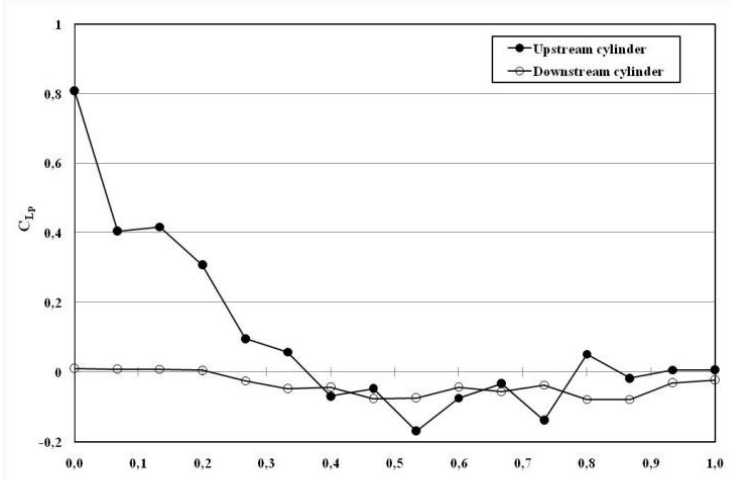

Figure 7. The variation of the pressure drag and lift coefficients with the gaps G/D for $\left.\operatorname{Re}=5.3 \times 10^{4}: a\right)$ drag and b) lift

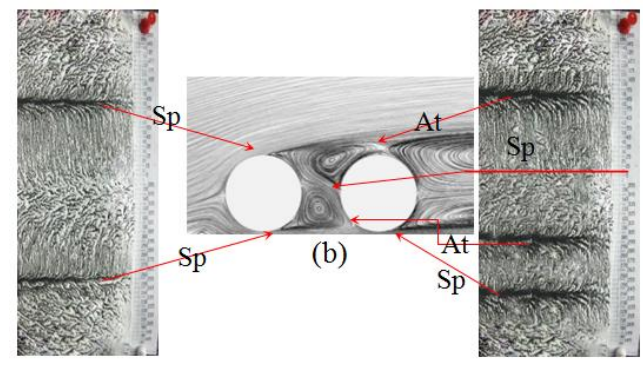

(a) (c)

Figure 8. Pressure distribution for $\mathrm{G} / \mathrm{D}=0.067$ and $\mathrm{R}_{\mathrm{e}}=5.3 \times 10^{4}$ in comparison between the present study and numerical results by [5]: (a) cylinder upstream, (b) numerical result by [5], and (c) cylinder downstream, $(\mathrm{Sp}=$ separation point, At $=$ attachment point $)$ 